\title{
Natural compounds, fraxin and chemicals structurally related to fraxin protect cells from oxidative stress
}

\author{
Wan Kyunn Whang ${ }^{1}$, Hyung Soon Park ${ }^{2}$, \\ InHye Ham ${ }^{1}$, Mihyun $\mathrm{Oh}^{1}$, \\ Hong Namkoong ${ }^{3}$, Hyun Kee $\mathrm{Kim}^{3}$, \\ Dong Whi Hwang ${ }^{2}$, Soo Young Hur ${ }^{4}$, \\ Tae Eung Kim ${ }^{4}$, Yong Gyu Park, \\ Jae-Ryong $\mathrm{Kim}^{6}$ and Jin Woo $\mathrm{Kim}^{3,4,7}$ \\ ${ }^{1}$ College of Pharmacy, Chung-Ang University \\ 221, Heukseok-dong, Dongjak-gu \\ Seoul 156-861, Korea \\ ${ }^{2}$ KeyGene Life Science Institute \\ KeyGene Science, Corp. \\ Ansan, Gyeonggido 425-791, Korea \\ ${ }^{3}$ Molecular Genetic Laboratory \\ Research Institute of Medical Science \\ ${ }^{4}$ Department of Obstetrics and Gynecology \\ ${ }^{5}$ Department of Biostatistics \\ College of Medicine \\ The Catholic University of Korea \\ Seoul 137-040, Korea \\ ${ }^{6}$ Department of Biochemistry and Molecular Biology \\ Aging-assoiciated Vascular Disease Research Center \\ College of Medicine, Yeungnam University \\ Daegu 705-717, Korea \\ ${ }^{7}$ Corresponding author: Tel, 82-2-590-2389; \\ Fax, 82-2-593-2389; E-mail jinwoo@catholic.ac.kr
}

Accepted 29 August 2005

Abbreviations: CAT, catalase; DCFH-DA, 2',7'-dichlorodihydrofluorescein-diacetate; DDRT-PCR, differential display reverse transcription-PCR; GPX, glutathione peroxidase; HUVECs, human umbilical vein endothelial cells; LPO, lipid peroxidation; MDA, malondialdehyde; RNS, reactive nitrogen species; ROS, reactive oxygen species; SOD, superoxide dismutase

\begin{abstract}
Coumarins comprise a group of natural phenolic compounds found in a variety of plant sources. In view of the established low toxicity, relative cheapness, presence in the diet and occurrence in various herbal remedies of coumarins, it appears prudent to evaluate their properties and applications further. The purpose of this study is to investigate cellular protective activity of coumarin compound, fraxin extracted from Weigela florida var. glabbra, under oxidative stress, to identify
\end{abstract}

genes expressed differentially by fraxin and to compare antioxidative effect of fraxin with its struc turally related chemicals. Of the coumarins, protective effects of fraxin against cytotoxicity induced by $\mathrm{H}_{2} \mathrm{O}_{2}$ were examined in human umbilical vein endothelial cells (HUVECs). Fraxin showed free radical scavenging effect at high concentration $(0.5 \mathrm{mM})$ and cell protective effect against $\mathrm{H}_{2} \mathrm{O}_{2}$-mediated oxidative stress. Fraxin recovered viability of $\mathrm{HUVECs}$ damaged by $\mathrm{H}_{2} \mathrm{O}_{2-}$ treatment and reduced the lipid peroxidation and the internal reactive oxygen species level elevated by $\mathrm{H}_{2} \mathrm{O}_{2}$ treatment. Differential display reverse transcription-PCR revealed that fraxin upregulated antiapoptotic genes (clusterin and apoptosis inhibitor 5) and tumor suppressor gene (ST13). Based on structural similarity comparing with fraxin, seven chemicals, fraxidin methyl ether $(29.4 \%$ enhancement of viability) prenyletin (26.4\%), methoxsalen (20.8\%), diffratic acid $(19.9 \%)$, rutoside $(19.1 \%)$, xanthyletin $(18.4 \%)$, and kuhlmannin (18.2\%), enhanced more potent cell viability in the order in comparison with fraxin, which showed only $9.3 \%$ enhancement of cell viability. These results suggest that fraxin and fraxin-related chemicals protect HUVECs from oxidative stress.

Keywords: antioxidants; apoptosis; coumarins; fraxin; oxidative stress; plants, medicinal

\section{Introduction}

Coumarins comprise a very large class of phenolic substances found in plants and are made of fused benzene and $\alpha$-pyrone rings. To date, at least 1,300 coumarins have been identified, principally as secondary metabolites in green plants but also in fungi and bacteria (Murray, 1989; Hoult and Paya, 1996). The prototypical compound is coumarin itself (also known as 1,2-benzopyrone or less commonly, as o-hydroxycinnamic acid-8-lactone), and it has been well studied. The pharmacological and biochemical properties and therapeutic applications of simple coumarins depend upon the pattern of substitution (Hoult and Paya, 1996).

Several natural products with a coumarinic moiety have been reported to have multiple biological activities (Ivanovska et al., 1994; Paya et al., 1994; Chang and Chiang, 1995; Chang et al., 1996; Fylaktakidou et al., 2004). It is to be expected that coumarins might affect the formation and sca- 
venging of ROS and influence processes involving free radical-mediated injury. Coumarin can reduce tissue edema and inflammation. Moreovercoumarin and its 7-hydroxy-derivative inhibit prostaglandin biosynthesis, which involves fatty acid hydroperoxy intermediates. Natural products like esculetin, fraxetin, daphnetin and other related coumarin derivatives are recognised as inhibitors not only of the lipoxygenase and cycloxygenase enzymic systems, but also of the neutrophil-dependent superoxide aniongeneration(Ivanovska etal .,1994;Paya etal., 1994; ChangandChiang,1995; Chang etal.,1996; Fylaktakidou et al., 2004). Coumarin derivatives have recently attracted much attention because of theirbroadpharmacologicalactivities.

Fraxin (7-hydroxy-6-methoxycoumarin 8-glucoside), structurallyaderivative ofacoumaringlucoside, isa colorless crystalline substance $\left(\mathrm{C}{ }_{16} \mathrm{H}_{18} \mathrm{O}_{10}\right)$ found in the bark of the ash (Fraxinus), and along with esculin in the bark of the horse-chestnut. It shows a delicate blue-green fluorescence in alkaline solutions;-calledalsopaviinandfraxoside.Fraxinshows its antioxidative effect through inhibition of cyclo AMP phosphodiesterase enzyme (Schempp et al., 2000). It also shows analgesic effect like a nonsteroidal anti-inflammatory drugs (von Kruedener et al., 1995; Klein-Galczinsky, 1999). Previous studies alsosuggested thatfraxin isolated from some plants showed various activities. Fraxin from Fraxinus excelsior had anti-inflammatory and antimetastatic properties, the former probably because of its direct action on cells, predominantly on macrophages inhibitory effect on 5-HETE production (Ivanovska et al., 1994). And the flowering or manna, ash, Fraxinus ornus $L$. [Fam. Oleaceae], the bark contains hydroxycoumarins, secoiridoid glucosides, phenylethanoids and flavonoids. Biological studies of hydroxycoumarins revealsignificantantimicrobial, antiinflammatory, immunomodulatory, antiviral and diureticactivitiesthatsupporttheuseofthisbarkinfolk medicine (Guarrera, 1999; Kostova, 2001). These results show that the traditional use of Fraxinus ornus stem bark in the treatment of inflammatory disorders is at least partially due to its coumarins constituents. Fraxin is also known to act as a choleretic agent for stimulating bile flow and aiding digestion, and has noted activity for preventing the development of abnormal growths (lossifova et al ., 1994). In the study of effect of some hydroxycoumarins on complement-mediated hemolysis in human serum, the interactions between esculin, esculetin, fraxin, fraxetin, as well as their acetylated and methylated derivatives and non-cell system participating in inflammatory processes, comprised of serum complement proteins, were investigated in vitro. Fraxin was able to enhance hemolysis (Ste- fanova etal ., 1995). In this study, as the constituent of the leaves of Weigela florida var. glabra (Caprifoliaceae), fraxin was studied phytochemically because theleaves of Weigelafloridavar.glabra have notbeenstudiedasmedicinalplant.

ROSandreactivenitrogenspecies(RNS)constantlygeneratedinnormalconditionbyaerobicmetabolism include free radicals such as superoxide anion, hydroxyl radicals, nonradical hydrogen peroxide, peroxinitrite, nitroxyl anion and nitric oxide (Beckman and Ames, 1998; Curtin et al., 2002; Droge, 2002). In normal biological systems, redox homeostasis is maintained by contro lling the balance between ROS production and various types of scavengers called antioxidants. Transient changes in oxidants-antioxidant balance are normally regulated by changing the production of counter species and reached to the steady-state over time (Shull et al., 1991; Nakamura et al., 1994; Adler et al., 1999; Zhang and Storz, 2000; Droge, 2002). The persistentproductionofabnormallylargeamountofROS orRNS, however, maylead to persistentchanges in signal transduction and gene expression, which in turnmaygiverisetocertaindiseases.

Various enzymaticand non-enzymatic selfdefense systems against oxidative stress including transientlyover-producedROSinsidecellsorexposureto externalROS inducing species have been identified and studied extensively. Catalase (CAT), SOD, and glutathione peroxidase (GPX) are the examples of enzymaticdefensesystemsandnon-enzymaticsystems include tocopherol, ascorbate, urate and glutathione(Sies, 1993).

The endothelium is known to be sensitive to injury causedbyROS(Valen etal.,1999), andincontrast, free radicals released by endothelial cells mediate the oxidation of low density lipid (LDL) (ZapolskaDownar et al., 1999). HUVECs have been used to study oxidative stress related researches and oxidative stress mediated by $\mathrm{H} \quad{ }_{2} \mathrm{O}_{2}$ damages cellular functions of HUVECs via various mechanisms (Valen etal., 1999;Estrada-Garcia etal., 2002; Waxman etal., 2003).

In the present study, we investigated cellular protective activity of coumarin compound, fraxin (7hydroxy-6-methoxycoumarin8-glucoside), underoxidative stress, identified genes expressed differentially by fraxine treatmentand compared antioxidant effectoffraxinwithitsstructurallyrelatedchemicals.

\section{Materials and Methods}

\section{Chemicals}

Fraxin was extracted from Weigela florida var. glabbra leaves (Caprifoliaceae), purified and characteri- 
zed as described (Morikawa et al., 2002). The methanolic extract was suspended with water and then partitioned with ether. The aqueous fraction was submitted to column chromatography on Diaion $\mathrm{HP}-20$ with gradientsolventsystemasfollows; $\mathrm{H} \quad{ }_{2} \mathrm{O}$, $20 \% \mathrm{MeOH}, 60 \% \mathrm{MeOH}, \mathrm{MeOH}$ (Jeong et al., 1999). The $20 \%$ and $60 \% \mathrm{MeOH}$ fractions were subjected to sephadex $\mathrm{LH}-20$ column chromatographyusing $15 \%, 50 \% \mathrm{MeOH}$ toyieldcompound. The structure of compound was elucidated by spectroscopicparameters of ${ }^{1} \mathrm{H}-\mathrm{NMR},{ }^{13} \mathrm{C}-\mathrm{NMR}, \mathrm{FT}$ IRandFAB-MS, andidentifiedasfraxin.

\section{HUVEC culture and cell viability assay}

HUVECswereobtained from full-term placentaafter delivery. Patient consent was obtained from each individual and the use of tissue samples was approved by the ethics committee of our institution. HUVECs were isolated from umbilical cords. Veins were cannulated and flushed first with phosphate-buffered saline (PBS) $(170 \mathrm{mM} \mathrm{NaCl}, 10 \mathrm{mM}$ $\mathrm{Na}_{2} \mathrm{HPO}_{4}, 3.3 \mathrm{mM} \mathrm{KCl}$, and $1.8 \mathrm{mM} \mathrm{KH} \quad{ }_{2} \mathrm{PO}_{4}, \mathrm{pH}$ 7.4 ) before being filled with $0.2 \%(\mathrm{v} / \mathrm{v})$ collagenase type II (Sigma, St. Louis, MO) in PBS. Following 10 min incubation at $37{ }^{\circ} \mathrm{C}(5 \% \mathrm{CO} 2)$, the collagenase was removed by flushing with $\mathrm{M}-199$ medium, and cells were centrifuged for $10 \mathrm{~min}$ at $1000 \quad \mathrm{~g}$. Cells were then resuspended in growth medium (M-199) andseededinto $25-\mathrm{cm}{ }^{2}$ cellculturedflaskpreviously coated with $1 \%(v / v)$ liquidgelatin(Sigma)withPBS. HUVECs were grown to confluence before starting the treatments in 96-well micro plates in a final volumeof100 ulculturemediumcontaining $10{ }^{4}$ cells per well. After allowing the cultures to grow to confluence, chemicals and $\mathrm{H} \quad{ }_{2} \mathrm{O}_{2}$ treatments were followedwithcertainintervals.

To determine the cell viability, XTT assay kit was used as described in company's manual (R\&D Systems Inc., Minneapolis, MN). Two cases of oxidativestresswereappliedtopre-incubatedHUVECs withchemicalsfor $1 \mathrm{~h}$ :thetreatmentwith $1 \mathrm{mMH}$ for $1 \mathrm{~h}$ and the treatmentwith $0.1 \mathrm{mMH} \quad{ }_{2} \mathrm{O}_{2}$ for $48 \mathrm{~h}$. Concentrationsoffraxinwerevariedfrom 0 to $0.5 \mathrm{mM}$.

\section{Analytical methods}

CAT activity was determined using Oxis research kit (OXISResearch, Portland, OR). After addition of 10 $\mathrm{mMH}_{2} \mathrm{O}_{2}$, cell lysates were incubated for 1 min and mixed with chromogen substrate followed by addition ofstopping reagent. Developed colorfor $10 \mathrm{~min}$ incubation was detected at $520 \mathrm{~nm}$. The rate of change in absorbance was converted to units of enzyme activity, determined from a standard curve using CAT. Enzyme activity was then standardized tomgprotein.
SOD enzymatic activity was determined using the assay described in Oxis research SOD-525 kit manual(OXISResearch, Portland, OR). In brief, cell lysates were treated with mercaptan eliminating reagent and chromogenic substrate of SOD was added to the samples. SOD activity was determined bymeasuringtheabsorbanceat525nmovertime. The extent of lipid peroxidation was determined by usingtheassaydescribedinOxisresearchLPO-586 kit manual (OXISResearch, Portland, OR). In brief, the LPO-586 assay is based on the reaction of a chromogenic reagent, $\mathrm{N}$-methyl-2-pheny liindole with malondialdehyde (MDA) and 4-hydroxyalkenals at $45^{\circ} \mathrm{C}$. One molecule of either MDA or 4-hydroxyalenal reacts with 2 molecules of reagent, $\mathrm{N}$-methyl2-phenyliindole, to yield a stable chromophore with maximalabsorbanceat586nm.

Intracellular ROS levels were determined by ROS mediated conversion of non-fluorescent $2^{\prime}, 7^{\prime}$-dichlorofluorescein diacetate(DCFH) to DCF. The study was performed by slight modification of a method describedpreviously(Zapolska-Downar etal.,1999). Cellswereculturedovernightin6-wellculture plates and preincubated with fraxin for $1 \mathrm{~h}$. Next, $1 \mathrm{mM}$ of $\mathrm{H}_{2} \mathrm{O}_{2}$ was added to the cells and the cells were incubatedfor $1 \mathrm{~h}$. Thecellswerewashed withM-199 media twice and followed by incubation with 0.02 mMDCFHfor 30 mininthedark. Afterincubation, 3 times of washing and lysis of the cells with $0.1 \%$ Triton X-100 in 0.1 M Tris was carried out. Relative fluorescence intensity ofDCF atanemission of 525 nmandanexcitation of $475 \mathrm{~nm}$ ofeachsamplewas measuredusingVictorV ${ }^{3}$ (Perkin-EImer). 1,1-diphenyl-3-picrylhydrazyl (DPPH) radical has a deep violet color due to its unpaired electron and radical scavenging can be followed spectrophotometrically by the loss of absorbance at $517 \mathrm{~nm}$ as the pale yellow non-radical form is produced. 0.08 $\mathrm{mM}$ ofDPPH solution in ethanol was prepared and added to various concentrations offraxin in ethanol. Absorbance changes at $517 \mathrm{~nm}$ for $10 \mathrm{~min}$ with 10 secofintervalweremonitored.

\section{Assessment of gene expression profiles in fraxin or $\mathrm{H}_{2} \mathrm{O}_{2}$ treated HUVECs}

Fordifferential display reverse transcription-polymerase chain reaction (DDRT-PCR) of $\mathrm{mRNA}$ (Liang and Pardee, 1992), HUVECs were obtained from full-term placenta after delivery. Total RNA was extracted from HUVECs treated with or without 0.2 $\mathrm{mM}$ of fraxin for $8 \mathrm{~h}$ using a RNA extraction kit (RNeasy total RNA kit; Qiagen Inc., Valencia, CA) and0.2 $\mu$ goftotalRNAwasused togeneratecDNA in a reverse transcription reaction (RNAimage ${ }^{\mathrm{TM}} \mathrm{kit}$, GenHunter, MA). With the use of the differential 
display kit (RNAimage ${ }^{\text {TM }}$ kit), we performed PCR using oligo-dT primers and arbitrary sequences, each 13 bases in length according to the manufacturer's recommendations. After cDNAs of 3' termini of mRNAs were generated, the PCR products were separated by electrophoresis on a $6 \%$ denaturing polyacrylamide gel. From the films, differentially expressed genes, which were overexpressed or downregulated in fraxin or $\mathrm{H}_{2} \mathrm{O}_{2}$ treated HUVECs, were identified and were then subcloned into the pGEM-T easy vector with the use of the TA cloning system, and subjected to an automatic sequencing analysis.

\section{Northern blot analysis}

The extracted total RNA of the cells was treated with DNase I and reverse transcribed with random hexamer priming (Clontech). By using the product as template, PCR was performed by using 5'-GGATGCCCTAAATGAGACCA-3' as the sense primer and 5'-GAGAGAAGGGCATCAAGCTG-3' as the antisense primer (Clusterin; GenBank accession no. BC010514). This RT-PCR product size was $455 \mathrm{bp}$. This 455-bp product was used as a probe for Northern blot analysis. Northern blot analysis was carried out, in which $20 \mu \mathrm{g}$ of denatured total RNA was electrophoresed on a $1.0 \%$ formaldehyde agarose gel and transferred to a nylon membrane (Roche Diagnostics $\mathrm{GmbH}$, Mannheim, Germany). Blot was hybridized with the randomly primed $\left[{ }^{32} \mathrm{P}\right]$-labeled 455-bp cDNA probe. Human $\beta$-actin cDNA control probe was used as a loading control.

\section{Comparison of fraxin and chemicals structurally related with fraxin in cell viability enhancement}

Based on structural similarity compared with fraxin, 18 chemicals showing more than $70 \%$ structural similarity were chosen among company's chemical library system. Structural similarity was calculated by ChemFinder (Cambridgesoft, MA). Basically same experimental procedure with previous cell viability assay was used for fraxin-related chemical screening except that the concentration of each chemical and $\mathrm{H}_{2} \mathrm{O}_{2}$ was fixed at $0.02 \mathrm{mM}$ and $0.2 \mathrm{mM}$, respectively. Chemicals were pretreated to HUVECs for $1 \mathrm{~h}$ and then cells were incubated with $0.2 \mathrm{mM}$ $\mathrm{H}_{2} \mathrm{O}_{2}$ for $1 \mathrm{~h}$. Less harsh condition $(0.2 \mathrm{mM})$ than 1 $\mathrm{mM}$ of $\mathrm{H}_{2} \mathrm{O}_{2}$ was used to increase selection ratio in this primary screening, which would give more information about the relationship between chemical structures and activities. HUVECs' survival was determined as about $60 \%$ at $0.2 \mathrm{mM} \mathrm{H}_{2} \mathrm{O}_{2}$ treatment. Experiments for each chemical were repeated three times and data were averaged. Viability recovery was calculated as relative recovery ratio, which means differences from cell viability of control. Con-

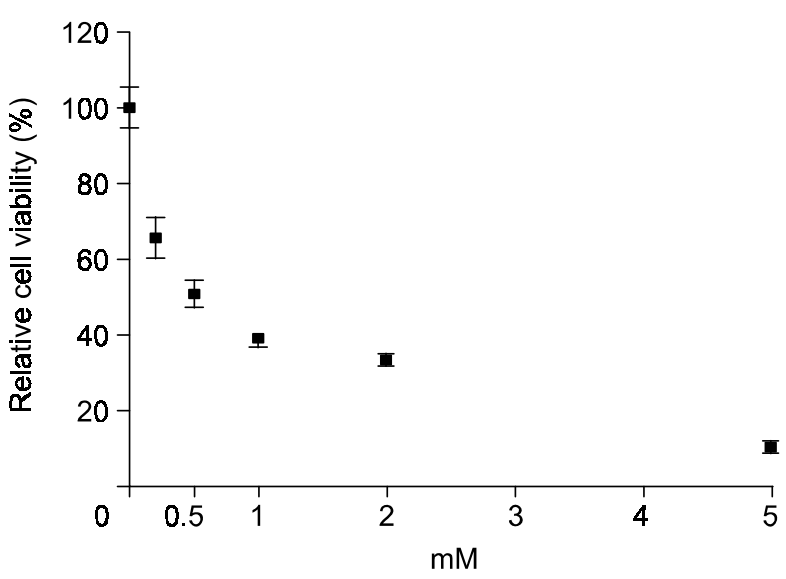

Figure 1. Cell viability dependent on the concentration of $\mathrm{H}_{2} \mathrm{O}_{2}$. Various concentrations of hydrogen peroxide (0-5 mM) were treated into HUVEC culture media and cell viability was assessed. $0.5 \mathrm{mM}$ of $\mathrm{H}_{2} \mathrm{O}_{2}$ induced about $50 \%$ cell death and $1 \mathrm{mM}$ of $\mathrm{H}_{2} \mathrm{O}_{2}$ resulted in about $60 \%$ cell death. Each value is the means $\pm \mathrm{SD}$ of three independent experiments.

trol is viabilities of cells treated with $\mathrm{H}_{2} \mathrm{O}_{2}$ alone.

\section{Results}

\section{Effects of $\mathrm{H}_{2} \mathrm{O}_{2}$ exposure on HUVECs in cell based assay}

Cell based assay is basically to monitor the change of cell viability induced by oxidative stress, which was $\mathrm{H}_{2} \mathrm{O}_{2}$ exposure on HUVECs in our experiments. Preliminary experiments were performed to determine the effects of $\mathrm{H}_{2} \mathrm{O}_{2}$ exposure on HUVECs (Figure 1). The concentration of $\mathrm{H}_{2} \mathrm{O}_{2}$ was varied from 0.2 to $5 \mathrm{mM}$ and cell death induced by $\mathrm{H}_{2} \mathrm{O}_{2}$ was monitored. Cell viability was also assessed after 0.5 , 1 or $2 \mathrm{~h}$. There were no significant differences in survival rate at each time point (data not shown). Cell viability was ranged from $70 \%(0.2 \mathrm{mM})$ to $10 \%$ $(5 \mathrm{mM})$ and $40 \%$ of cells were viable at $1 \mathrm{mM} \mathrm{H}_{2} \mathrm{O}_{2}$ (Figure 1). Therefore, $1 \mathrm{mM} \mathrm{H}_{2} \mathrm{O}_{2}$ was used through all subsequent screenings to differentiate the effects of survival and death by chemicals.

\section{Primary screening of fraxin using cell based assay} Fraxin was extracted, purified from Weigela florida var. glabbra and used as primary screening material to investigate whether fraxin is an effective antioxidative chemical, which may protect cells from oxidative stress. Since cell based assay is more direct assay to select antioxidative chemicals, it was employed as primary screening assay. Three different concentrations $(0.02,0.1$, and $0.5 \mathrm{mM})$ of fraxin were treated for $1 \mathrm{~h}$ prior to the addition of $1 \mathrm{mM}$ 
$\mathrm{H}_{2} \mathrm{O}_{2}$ and relative cell viabilities in comparison to HUVECs alone were monitored (Figure 2A). In addition to high concentration of $\mathrm{H}_{2} \mathrm{O}_{2}$ treatment (1 $\mathrm{mM})$, low concentration of $\mathrm{H}_{2} \mathrm{O}_{2}(0.1 \mathrm{mM})$ was introduced into HUVECs for $48 \mathrm{~h}$ to evaluate fraxin that may protect cells exposed to $\mathrm{H}_{2} \mathrm{O}_{2}$ at low concentration and for long time (Figure $2 \mathrm{~B}$ ). Fraxin improved cell survival rate more than $50 \%$ at $0.1 \mathrm{mM}$ in cells exposed to $\mathrm{H}_{2} \mathrm{O}_{2}$ at high concentration (1 $\mathrm{mM}$ ) and for short time (1 h) (about $40 \%$ cell survival rate) (Figure 2A). But in cells exposed to $\mathrm{H}_{2} \mathrm{O}_{2}$ at low concentration $(0.1 \mathrm{mM})$ and for long time (48 h) (about $20 \%$ cell survival rate), fraxin improved cell survival rate more than $35 \%$ at $0.5 \mathrm{mM}$ (Figure $2 \mathrm{~B}$ ).

\section{SOD and CAT assays}

In the present experiment, $\mathrm{H}_{2} \mathrm{O}_{2}$ exposure on HUVECs resulted in no significant change in either SOD or CAT activities in HUVEcs and fraxin also did not affect activities of both enzymes in HUVECs (data not shown).
A

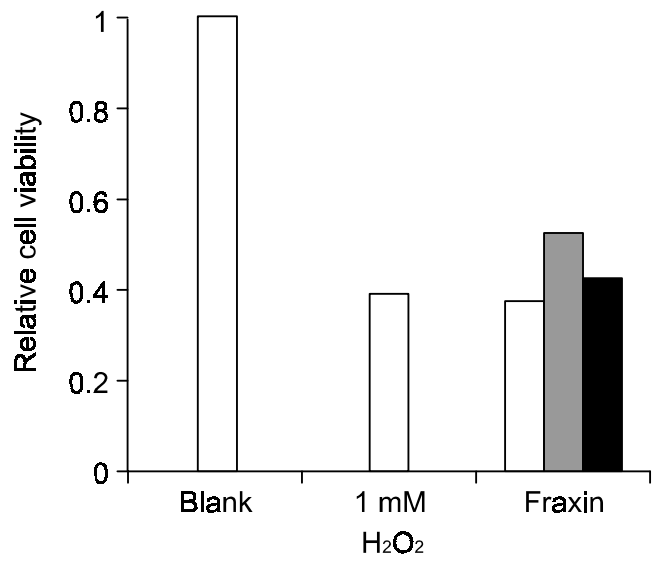

B

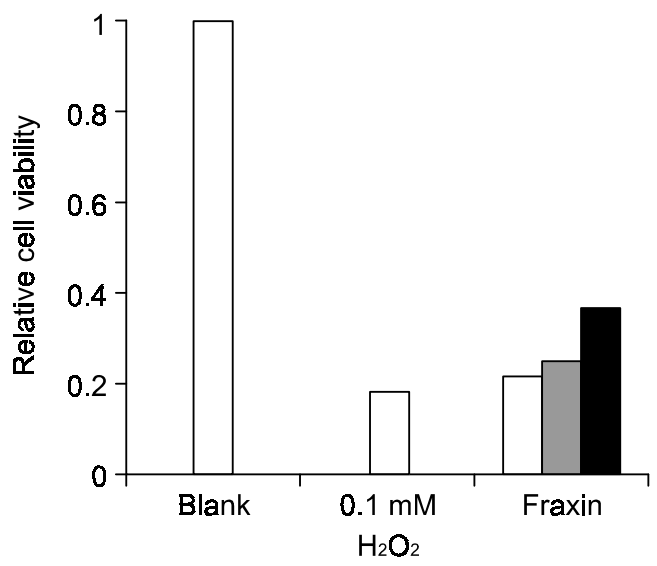

Figure 2. Primary screening of fraxin using cell based assay. Cell viability assays were performed with three different concentrations of fraxin. Prior to incubation with $\mathrm{H}_{2} \mathrm{O}_{2}$, HUVECs were treated with 0.02 (opened bar), 0.1 (grey bar) and 0.5 (black bar) $\mathrm{mM}$ of fraxin for $1 \mathrm{~h}$, respectively and then followed by $1 \mathrm{~h}$ incubation in $1 \mathrm{mM} \mathrm{H}_{2} \mathrm{O}_{2}(\mathrm{~A})$ and $48 \mathrm{~h}$ incubation in $0.1 \mathrm{mM} \mathrm{H}_{2} \mathrm{O}_{2}(\mathrm{~B})$. Blank denotes untreated control HUVECs.

A

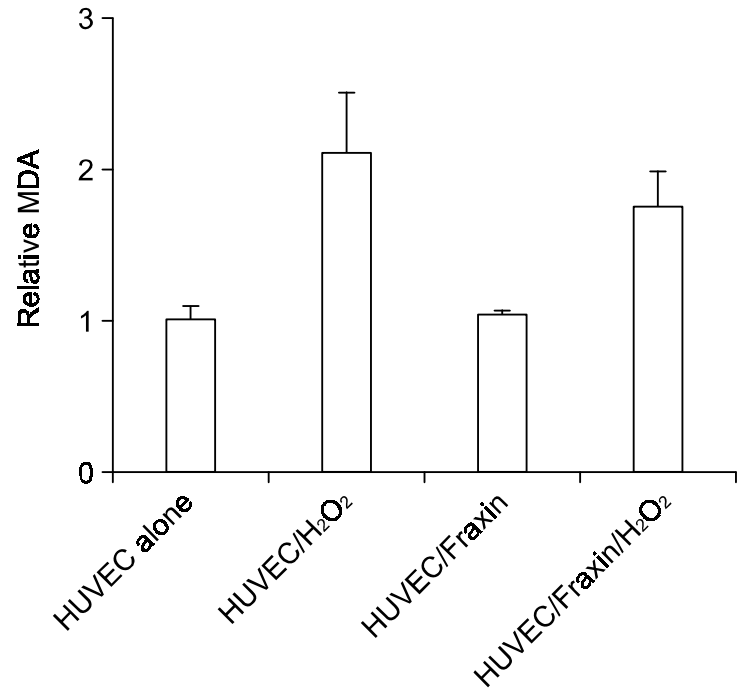

B

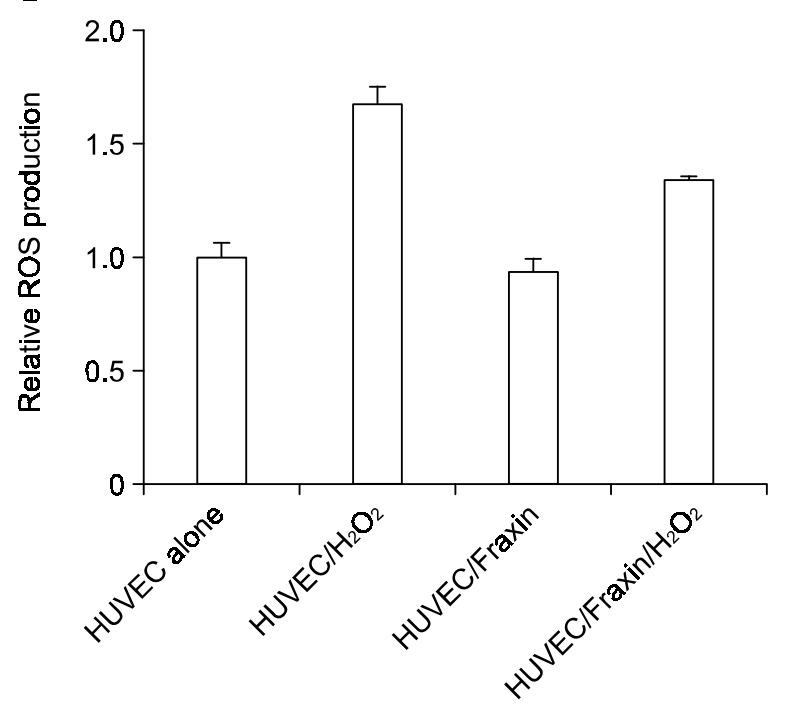

Figure 3. Intracellular LPO and ROS production. (A) LPO production of HUVECs with the treatment with $\mathrm{H}_{2} \mathrm{O}_{2}$ and/or fraxin. (B) Intracellular ROS production detected by DCF with the treatment with $\mathrm{H}_{2} \mathrm{O}_{2}$ and/or fraxin. Each value is the means $\pm \mathrm{SD}$ of three independent experiments. 


\section{LPO assay and production of ROS}

MDA level obtained from fraxin treatment on HUVECs alone was similar to the level in the HUVEC cultures without oxidative stress (Figure $3 \mathrm{~A})$. When the cells are treated with $\mathrm{H}_{2} \mathrm{O}_{2}$, however, there was a significant increase of MDA production to about $210 \%$. This elevated MDA level was decreased to about $190 \%$ with treatment of fraxin prior to the addition of $\mathrm{H}_{2} \mathrm{O}_{2}$ (Figure $3 \mathrm{~A}$ ). Treatment with fraxin showed a protector effect with about $20 \%$ decrease in MDA production induced by $\mathrm{H}_{2} \mathrm{O}_{2}$.

To address the possibility that the increased cell viability in the presence of phytochemicals is due to decreased production of ROS inside cells, we measured intracellular concentrations of $\mathrm{H}_{2} \mathrm{O}_{2}$ in HUVECs. The effect of fraxin on cellular oxidation was determined by DCF fluorescence. HUVECs activated by $\mathrm{H}_{2} \mathrm{O}_{2}$ showed an increase in free radical level by about $60 \%$ over non-treated HUVECs (Figure 3B). Pretreatment with fraxin prior to the addition of $\mathrm{H}_{2} \mathrm{O}_{2}$ decreased intracellular $\mathrm{H}_{2} \mathrm{O}_{2}$ levels to about 39\% (Figure 3B). Since fraxin showed high ROS scavenging effect, direct scavenging of ROS

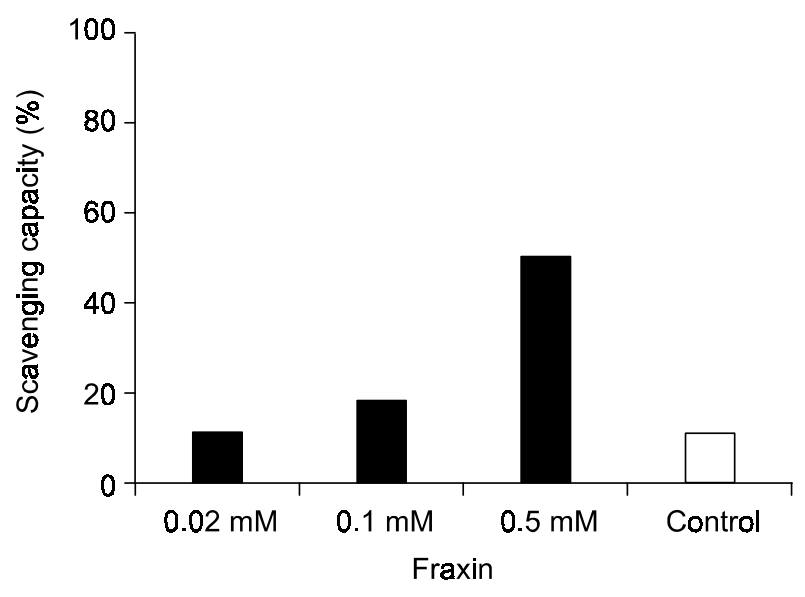

Figure 4. Free radical scavenging activity of fraxin. Free radical scavenging ability of fraxin determined by using DPPH assay. Eighty $\mu \mathrm{M}$ of DPPH solution in ethanol was prepared and added to various concentrations of chemical $(0.02,0.1$ and $0.5 \mathrm{mM})$ in ethanol. Absorbance changes at $517 \mathrm{~nm}$ for 10 min with $10 \mathrm{~s}$ of interval were monitored. Each value is the means $\pm S D$ of three independent experiments. by fraxin could account for reduced intracellular $\mathrm{H}_{2} \mathrm{O}_{2}$.

\section{Free radical scavenging activity}

Fraxin exposure on HUVECs showed very high free radical scavenging activity at high concentration (Figure 4). At $0.5 \mathrm{mM}$, about $50 \%$ of free radicals were quenched. But free radical scavenging ability of fraxin was not efficient at used concentrations $(0.02 \mathrm{mM})$.

\section{Differential display and northern blot analysis}

Using the DDRT-PCR, genomic expression levels in HUVECs were estimated after $\mathrm{H}_{2} \mathrm{O}_{2}$ exposure or fraxin treatment, respectively. Differentially expressed mRNAs by fraxin or $\mathrm{H}_{2} \mathrm{O}_{2}$ treatment were selected and compared to each other. Among identified genes, the change of gene expression pattern by fraxin in comparison to untreated HUVECs was interesting and unique. Fraxin upregulated antiapoptotic genes (clusterin and apoptosis inhibitor 5) and tumor suppressor gene (ST13) (Table 1). Among three identified genes, clusterin, apoptosis inhibitor 5 and ST13 putative tumor suppressor, by

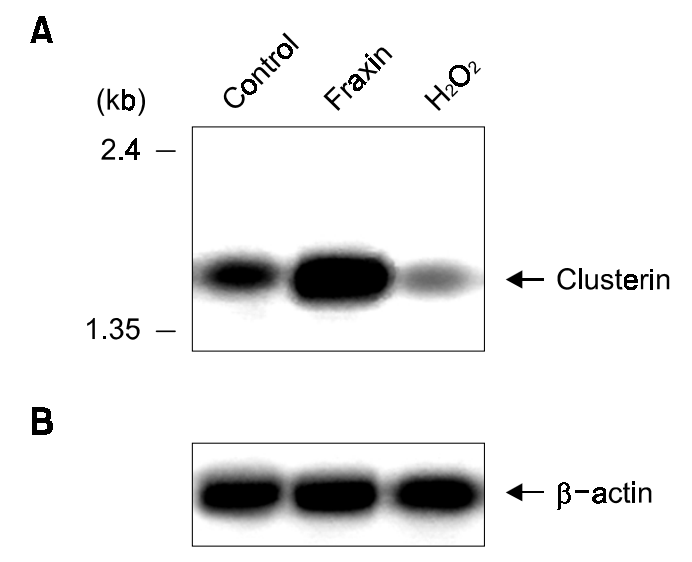

Figure 5. Clusterin gene expressions in HUVECs. Northern blot analysis was performed to determine the expression pattern in HUVECs. Blot was hybridized with the randomly primed [ $\left.{ }^{32} \mathrm{P}\right]$-labeled 455 -bp cDNA probe for clusterin. Human $\beta$-actin CDNA probe was used as a loading control.

Table 1. Patterns of differentially expressed genes by fraxin or $\mathrm{H}_{2} \mathrm{O}_{2}$.

\begin{tabular}{llll}
\hline \multicolumn{3}{c}{ Expression level } & \\
\cline { 1 - 3 } Control & Fraxin & $\mathrm{H}_{2} \mathrm{O}_{2}$ & \\
\cline { 1 - 2 } Medium & Strong & Weak & SP40, SGP-2, Clusterin (anti-apoptotic activity) \\
Weak & Medium & Weak & Apoptosis inhibitor 5 \\
Weak & Strong & Weak & HSP interacting protein (Hip). ST13 Putative tumor suppressor \\
\hline
\end{tabular}


using the DDRT-PCR, clusterin showed the most strong upregulation after treatment with fraxin compared with apoptosis inhibitor 5 or ST13 putative tumorsuppressor(Table1).Accordinglyweperformed Northern blot analysis to reconfirm the upregulation of clusterin in fraxin-treated HUVECs. As expected, clusterin was upregulated in fraxin-treated HUVECs compared to control HUVECs or $\mathrm{H} \quad{ }_{2} \mathrm{O}_{2}$ treatedHUVECs(Figure5).

\section{Cell viability assay with chemicals structurally related to fraxin}

Based on structural similarity compared with fraxin,
18 chemicals showing more than $70 \%$ structural similarity were chosen and previous cell viab ility assay was used for fraxin-related chemical screening (Table 2). Through viab ility assay, seven chemicals related to fraxin showed more than $18 \%$ (two-fold) enhancement of viab ility in comparison withcontrol(Table2andFigure6).Sevenchemicals related tofraxinwerefraxidinmethylether(chemical No. 1, 29.4\% enhancement of viab ility), prenyletin (chemicalNo.2,26.4\%), methoxsalen(chemicalNo. 3, $20.8 \%$ ), diffratic acid (chemical No. 4, 19.9\%), rutoside (chemical No. 5, 19.1\%), xanthyletin (chemical No. 6, 18.4\%), and kuhlmannin (chemical No. $7,18.2 \%$ ) (Figure 6). Percentages in parenthesis

Table 2. Screening results of fraxin-related chemical library.

\begin{tabular}{|c|c|c|c|c|c|c|c|}
\hline No. & Structure & Name & $\begin{array}{c}\text { Survival } \\
(\%)\end{array}$ & No. & Structure & Name & $\begin{array}{c}\text { Survival } \\
(\%)\end{array}$ \\
\hline 1 & & $\begin{array}{l}\text { FRAXIDIN } \\
\text { METHYL } \\
\text { ETHER }\end{array}$ & 29.4 & 11 & & SCOPOLETIN & 15.5 \\
\hline 2 & & PRENYLETIN & 26.4 & 12 & & DIOSMIN & 11.9 \\
\hline 3 & & $\begin{array}{l}\text { METHOXSAL } \\
\text { EN }\end{array}$ & 20.8 & 13 & & HERNIARIN & 9.2 \\
\hline 4 & & $\begin{array}{l}\text { DIFFRATIC } \\
\text { ACID }\end{array}$ & 19.9 & 14 & & CITROPTEN & 9.0 \\
\hline 5 & & RUTOSIDE & 19.1 & 15 & & $\begin{array}{l}\text { DIHYDRO- } \\
\text { OBLIQUIN }\end{array}$ & 7.5 \\
\hline 6 & & XANTHYLETIN & 18.4 & 16 & & CITROPTEN & 5.0 \\
\hline 7 & & KUHLMANNIN & 18.2 & 17 & & DICUMAROL & -9.2 \\
\hline 8 & & WARFARIN & 17.8 & 18 & & BERGAPTENE & -92.7 \\
\hline 9 & & QUERCITRIN & 17.0 & FX & & Fraxin & 9.3 \\
\hline 10 & & AESCULIN & 16.6 & & & & \\
\hline
\end{tabular}




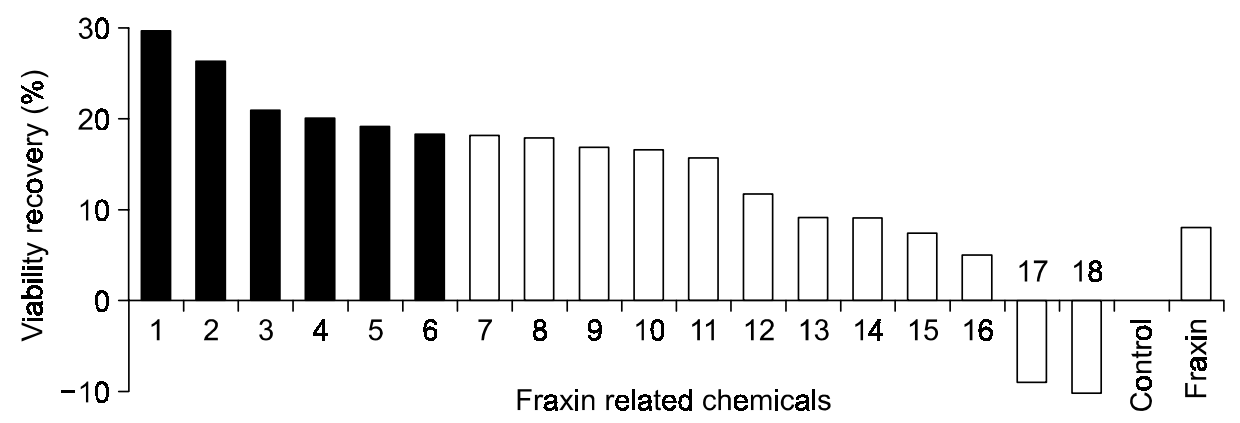

Figure 6. Cellviabilityrecovery of 18 structurallyfraxin-relatedchemicals. Filledbarsindicatefraxin-relatedchemicalsshowingcel andopenedbarsindicatefraxin-relatedchemicalsshowingcellviabilityunder $18 \%$.Experimentsforeachchemicalwererepeated wereaveraged.Viabilityrecoverywascalculatedasrelativere coveryratio, whichmeansdifferencesfromcellviabilityofcon bilityofcellstreatedwith $\mathrm{H}_{2} \mathrm{O}_{2}$ alone. trol.Controldenotesvia-

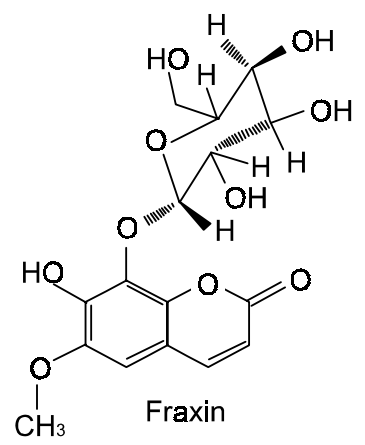<smiles>COc1cc2ccc(=O)oc2c(OC)c1OC</smiles>

Fraxidin methyl ether<smiles>CC(C)=CCOc1cc2oc(=O)ccc2cc1O</smiles>

Prenyletin<smiles>COc1c2occc2cc2ccc(=O)oc12</smiles><smiles>CC1(C)C=Cc2cc3ccc(=O)oc3cc2O1</smiles>

Methoxsalen

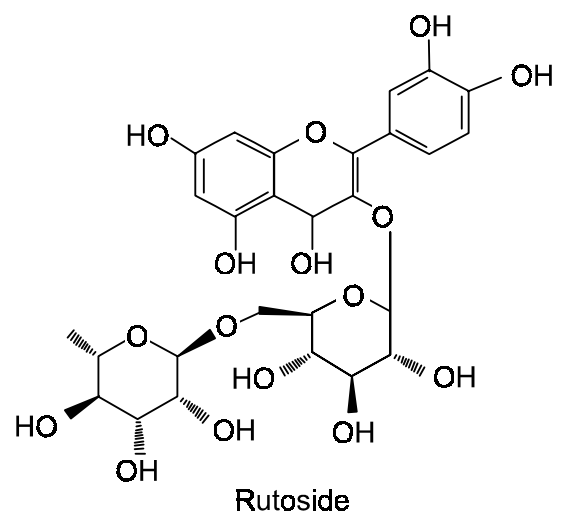

Xanyhyletin<smiles>COc1cc(C)c(C(=O)Oc2cc(C)c(C(=O)O)c(O)c2C)c(OC(Cl)(Cl)Cl)c1[18O]</smiles><smiles>COc1c(O)cc2c(-c3ccccc3)cc(=O)oc2c1OC</smiles>

Kuhlmannin

Figure7. Thechemicalstructureoffraxin and seven chemicals, fraxidin methyl ether, prenyletin, methoxsalen, diffratic acid, rutoside, xanthyletinand kuhlmannin. indicate the relative viability enhancement. Fraxidin methyl ether showed the highest activity among tested 18chemicals. These 7 chemicalswereselected as primary hits since those were considered as che- micals showing significant enhancement of viability in comparison with fraxin, which showed only $9.3 \%$ enhancementofcellviability(Table2andFigure7). 


\section{Discussion}

Reducingreactiveoxygenspeciesinthebodyisone of main efforts towards protection of various diseases such as aging process, cancer, diabetes and neurodegenerative diseases. Many natural products including flavonoids, coumarins, polyols have been studiedforthecharacterizationand thedevelopment asantioxidativereagents(FinkelandHolbrook, 2000; Han,2003;Whang etal., 2005).

Coumarins comprise a group of phenolic compounds widely distributed in natural plants (Egan al., 1990; Kaneko et al., 2003), and they have recently attracted much attention because of their broadpharmacologicalactivities. Among thesecompounds, esculetin (6,7-dihydroxycoumarin) shows scavengingactivityagainstROSsuchassuperoxide radicals (Chang et al ., 1996) and hydroxyl radicals (Hiramoto etal .,1996), andinhibitslipidperoxidation in rat livers (Martin-Aragon et al ., 1998). But fraxin (7-hydroxy-6-methoxycoumarin 8-glucoside), a coumarin derivative, was shown neither to inhibit lipid peroxidation nor to scavenge superoxide radicals or hypochlorousacid toanysignificantextent, although fraxin was capable of rapidly reacting with hydroxyl radicals, and fraxin scavenged alkyperoxy radicals with useful potency (Hoult and Paya, 1996). Inconsistent with previous observations (Hoult and Paya, 1996), cellbasedassayusedinthisstudytomonitor the change of cell viab ility i nduced by oxidative stress revealed that fraxin enhanced the viab ility of HUVECs.

In our studies, fraxin showed protective effects against $\mathrm{H}_{2} \mathrm{O}_{2}$-mediated oxidative stress. Recovering the viability of dam aged HUVECs and reducing the LPO and the internal ROS level by fraxin clearly explains the protective effect against oxidative stress. Although free radical scavenging ab ility of fraxin was not efficient at used concentration $(0.02$ $\mathrm{mM})$, about $50 \%$ of free radicals were quenched at high concentration $(0.5 \mathrm{mM})$. While fraxin did not affect the biological activities involved in antioxidative mechanisms such as catalase and SOD in the biological systems, induced lipid peroxidation andinternalROSlevelbyH $\quad{ }_{2} \mathrm{O}_{2}$ intheHUVECswere reduced by fraxin treatment. From these results, direct deactivation of ROS probably is primary reason for the protective effect of fraxin from $\mathrm{H}_{2} \mathrm{O}_{2}$-mediatedoxidativestress.

To find out more efficient antioxidants from the fraxin derivatives, 18 chemicals showing more than $70 \%$ structuralsimilaritywith fraxinwerechosenand cell viability assay was used for fraxin-related chemical screening. Through viab ility assay, seven chemicals related to fraxin showed more than $18 \%$ enhancement of viab ility in comparison with control.
Seven chemicals related to fraxin were fraxidin methyl ether, prenyletin, methoxsalen, diffratic acid, rutoside, xanthyletin and kuhlmannin. Fraxidin methyl ether showed the highest enhancement of cell viability (29.4\%) am ong tested 18 chemicals. Fraxidin with a coumarinic moiety has been reported to have several beneficial properties, including antioxidant, anti-inflammatory, and anti-diabetogenic effects(Kimura etal.,1985; Kim etal., 1999; Fort et al., 2000). In polymorphonuclearleukocytes, fraxidin inhibited the formation of the cyclooxygenase product, hydroxy-5,8,10-heptadecatrienoic acid (HHT), strongly by inhibition of the formation of 5-hydroxy$6,8,11,14$-eicosatetraenoic acid from arachidonic acid (Kimura et al ., 1985). It is to be expected that fraxidin can reduce tissue edema and inflammation. Moreoverfraxidininhibited the formation ofinducible nitric oxide synthase (Kim etal ., 1999) and showed antihyperglycemic activity (Fort etal ., 2000). These 7 chemicals including fraxidine were selected as primary hits since those were considered as chemicals showing significant enhancement of viab ility incomparison with fraxin. Furtherinvestigation would be necessary to optimize its activity and druglikenessforthedevelopmentasadrugcandidate. When the perturbation of cells by exogenous oxidants such as $\mathrm{H}_{2} \mathrm{O}_{2}$ is severe, cells may respond in two different ways, survival or insult by undergoing cell death. In cellular systems, a number of stress response mechanisms help cells adopt damage or resist to the stress. In general, the heat shock response and the ERK, PI3K/Aktand NF-kB signaling pathways exert a pro-survival influence against oxidative damages. In contrast, activation of p53, JNK and p38 are linked to apoptosis, which leads damaged cells to the death to remove from the multi-cellularsystems(FinkelandHolbrook,2000). To link the evidences of antioxidative $a b$ ility of fraxin to molecular mechanisms, the analysis of gene expression patterns by differential display method wascarried out. Ourresults suggestalternative mechanisms for the antioxidative effects of fraxin. Differential display RT-PCR revealed that fraxin upregulatedanti-apoptoticgenes (clusterinandapoptosis inhibitor 5) and tumor suppressor gene (ST13). This finding is interesting thatfraxininduced anti-apoptoticgenes(Wolfand Green, 2002; Thiede and Rudel, 2004) because apoptosis and aging share common mechanisms in oxidative stress and mitochondrialinvolvement(Lenaz etal.,1998).Cells in the brain deploymultiple mechanisms to maintain the integrity of nerve cell circuits, and to fac ilitate responses to environmental demands and promote recovery of function after injury (McGeer et al ., 1992). The mechanisms include production of neurotrophic factors and cytokines, expression of 
various cell survival-promoting proteins (e.g. protein chaperones, antioxidant enzymes, Bcl-2 and inhibitor of apoptosis proteins), protection of the genome by telomerase and DNA repair proteins, and mobilization of neuralstemcellstoreplacedamaged neuronsandglia(McGeer etal.,1992).

Clusterin, a secreted mammalian chaperone, is upregulated in response to complement membrane attack complex formation in Alzheimer disease (Koch-Brandt and Morgans, 1996; Wilson and Easterbrook-Smith, 2000). Clusterin is a cell survival gene, exerting a protective function on the surviving bystandercells. Basedontheseresultsthatclusterin and apoptosis inhibitor 5 regulate apoptosis and survival signaling pathways for the cell survival, cellular protective ability of fraxin against oxidative stressmaybelinked totheinductionofclusterinand apoptosis inhibitor 5 genes by fraxin. These results suggest that fraxin-induced genes may play roles in cellularprotective functions offraxin. Furtherinvestigationwithidentifiedgenesisintensivelyundergoing to support this preliminary linkage between antioxidative activities and molecular mechanisms involvedinfraxin-mediatedcellsurvival.

This study suggests that fraxin and fraxin-related chemicals protectHUVECs from oxidative stress. In view of the established low toxicity, relative cheapness, presencein the dietandoccurrence invarious herbal remedies of coumarins, itappears prudent to evaluate their properties and applications further. Furtherstudiesareneededinvariousnormalhuman cells including immune cells regarding its antioxidativeandneo-vascularizationeffects.

\section{Acknowledgement}

This study was supported by a grant of the Korea Health21R\&DProject, MinistryofHealth\&Welfare, RepublicofKorea(02-PJ10-PG6-AG01-0003).

\section{References}

Adler V, Yin Z, Fuchs SY, Benezra M, Rosario L, Tew KD, PincusMR, SardanaM, HendersonCJ, WolfCR, DavisRJ, Ronai Z. Regulation of JNK signaling by GSTp. EMBO J 1999;18:1321-34

Beckman KB, Ames BN. The free radical theory of aging matures.PhysiolRev1998;78:547-81

Chang WS, Chiang HC. Structure- activity relationship of coumarins in xanthine oxidase inhibition. Anticancer Res 1995;15:1969-73

Chang WS, Lin CC, Chuang SC, Chiang HC. Superoxide anion scavenging effect of coumarins. Am J Chin Med 1996;24:11-7

Curtin JF, Donovan M, Cotter T. Regulation and mea- surement of oxidative stress in apoptosis. J Immunol Methods2002;265:49-72

Droge W. Free radicals in the physiological control of cell function.Physiol Rev2002;82:47-95

EganD,O'KennedyR,MoranE, CoxD,ProsserE,Thornes $\mathrm{RD}$. The pharmacology, metabolism, analysis, and applicationsofcoumarinandcoum arin-relatedcompounds.Drug MetabolRev1990;22:503-29

Estrada-Garcia L, Carrera-Rotll an J, Puig-Parellada P. Effects of oxidative stress and antioxidant treatments on eicosanoid synthesis and lipid peroxidation in long term human umbilical vein endothelial cells culture. ProstaglandinsOtherLipi dMediat2002;67:13-25

Finkel T, Holbrook NJ. Oxi dants, oxidative stress and the biologyofaging.Nature2000;408:239-47

Fort DM, Rao K, Jolad SD, Luo J, Carlson TJ, King SR. Antihyperglycemic activity of Teramnus labialis (Fabaceae). Phytomedicine2000;6:465-7

Fylaktakidou KC, Hadjipavl ou-Litina DJ, Litinas KE, Nicolaides DN. Natural and synt hetic coumarin derivatives withanti-inflammatory/antioxidant activities.CurrPharmDes 2004;10:3813-33

Guarrera PM. Traditional antihelmintic, antiparasitic and repellent uses of plants in Central Italy. J Ethnopharmacol 1999;68:183-92

HanMK.Epigallocatechingallate,aconstituentofgreentea, suppresses cytokine-induced pancreatic beta cell damage. ExpMolMed2003;35:136-9

Hiramoto K, Ojima N, Sako K, Kikugawa K. Effect of plant phenolics on the formation of $t$ he spin-adduct of hydroxyl radicalandtheDNAstrandbreaking byhydroxylradical.Biol PharmBull1996;19:558-63

HoultJR,PayaM.Pharmacol ogicalandbiochemicalactions of simple coumarins: natur al products with therapeutic potential.GenPharmacol1996;27:713-22

IossifovaT,KujumgievA, IgnatovaA,VassilevaE,Kostoval. Antimicrobial effects of so me hydroxycoumarins and secoiridoidsfromFraxinusornus bark.Pharmazie1994;49:298-9

Ivanovska N, Yossifova T, VassilevaE, Kostoval. Effect of some hydroxycoumarins on complement-mediated hemoIysis in human serum. Methods Find Exp Clin Pharmacol 1994;16:557-62

JeongMH,YoonHM,Haml,JungMY,WhangWK.Phenolic compounds from leaves of Weigela florida var. glabra. J PharmSci1999:13:23-31

Kaneko T, Baba N, Matsuo M. Protection of coumarins against linoleic acid hydroper oxide-induced cytotoxicity. ChemBiollnteract2003;142:239-54

KimNY,PaeHO,KoYS, YooJC,ChoiBM,JunCD,Chung $\mathrm{HT}$, Inagaki M, Higuchi R, Kim YC . . In vitro inducible nitric oxide synthesis inhibitory acti ve constituents from Fraxinus rhynchophylla.PlantaMed1999;65:656-8

KimuraY,OkudaH,ArichiS, BabaK, KozawaM. Inhibition oftheformationof5-hydroxy- 6,8,11,14-eicosatetraenoicacid 
from arachidonic acid in pol ymorphonuclear leukocytes by variouscoumarins.Bioc himBiophysActa1985;834:224-9

Klein-Galczinsky C. Pharmaco logical and clinical effectiveness of a fixed phytogenic combination trembling poplar (Populus tremula), true goldenr od (Solidago virgaurea) and ash (Fraxinus excelsio) in mild to moderate rheumatic complains.WienMedWochenschr1999;149:248-53

Koch-BrandtC, Morgans C. Clusterin: a role in cell survival in the face of apoptosis? Prog Mol Subcell Biol 1996; $16: 130-49$

Kostoval. Fraxinusornus L.Fitoterapia2001;72:471-80

LenazG,CavazzoniM,GenovaML,D'AurelioM,MerloPich M, Pallotti F, Formiggini G, Ma rchetti M, Parenti Castelli G, BovinaC.Oxidativestress, antioxidantdefencesandaging. Biofactors 1998;8:195-204

Liang $P$, Pardee AB. Different ial display of eukaryotic messengerRNAbymeansoft hepolymerasechainreaction. Science1992;257:967-71

Martín-Aragón S, Benedí JM, Villar AM. Effects of the antioxidant (6,7-dihydroxycoumarin) esculetin on the glutathine system and lipid peroxi dation in mice. Gerontology 1998;44:21-5

McGeer PL, Kawamata T, Walker DG. Distribution of clusterin in Alzheimer brai $\mathrm{n}$ tissue. Brain Res 1992;579: 337-41

Morikawa T, Tao J, Ueda K, Matsuda H, Yoshikawa M. Medicinal foodstuffs. XXXI. St ructures of new aromatic constituents and inhibitors of degiannulation in RBL-2H3 cellsfroma Japanesefolkmedi cine. ThestembarkofAcer nikonensis.ChemPharmBull2002;51:62-7

\section{MurrayRD.Coumarins.Na tProdRep1989;6:591-624}

Nakamura H, Matsuda M, Furuke K, Kitaoka Y, Iwata S, TodaK, Inamoto T, Yamaoka Y, Ozawa K, Yodoi J. Adult T cell leukemia-derived factor /human thioredoxin protects endothelialF-2cellinjurycaused byactivatedneutrophilsor hydrogenperoxide.Im munolLett1994;42:75-80

Paya M, Goodwin PA, De Las Heras B, Hoult JR. Superoxide scavenging activity in leukocytes and absence of cellulartoxicityofaseries ofcoumarins.BiochemPharmacol 1994;48:445-51

Schempp H, Weiser D, Elstner EF. Biochemical model reactions indicative of inflamma tory processes. Activities of extracts from Frxinus excelsio and Populus tremula. Arzneimittelforschung2000;50:362-72
ShullS, HeintzNH,PeriasamyM,ManoharM,JanssenYM, MarshJP,MossmanBT.Differentialregulationofantioxidant enzymes in response to oxidants. J Biol Chem 1991;266: 24398-403

Sies H. Strategies of antio xidant defense. Eur J Biochem 1993;215:213-9

StefanovaZ,NeychevH,Ivanovska N,Kostoval.Effectofa total extract from Fraxinus ornus stem bark and esculin on zymosan-andcarrageenan-inducedpawoedemainmice.J Ethnopharmacol1995;46:101-6

Thiede B, Rudel T. Proteom e analysis of apoptotic cells. MassSpectromRev2004;23:333-49

Valen G, Sonden A, Vaage J, Malm E, Kjellstrom T. Hydrogen peroxide induces endothelial cell atypia and cytoskeleton depolymerization. Free Radic Biol Med 1999; 26:1480-8

vonKruedenerS,SchneiderW,ElstnerEF.Acombinationof Populus tremula, Solidago vi rgaurea and Frxinus excelsior as a anti-inflammatory and antirheumatic drug. A short review.Arzneimittelforschung1995;45:169-71

Waxman AB, Mahboubi K, Kni ckelbein RG, Mantell LL, Manzo N, Pober JS, Elias JA. Interleukin-11 and interleukin-6 protect cultured human endothelial cells from $\mathrm{H}_{2} \mathrm{O}_{2}$-induced cell death. Am J Respir Cell Mol Biol 2003; 29:513-22

Whang WK, Park HS, Ham IH, Oh M, NamKoong H, Kim HK, Hwang DW, Hur SY, Kim TE, Park YG, Kim JR, Kim $\mathrm{JW}$. Methyl gallate and chemicals structurally related to methylgallateprotecthumanumbilicalveinendothelialcells fromoxidativestress. ExpMolMed2005;37:343-52

Wilson MR, Easterbrook-Smith SB. Clusterin is a secreted mammalianchaperone.TrendsBiochemSci2000;25:95-8

WolfBB, Green DR. Apoptosis: letting slip the dogs of war. CurrBiol2002;12:R177-9

Zapolska-Downar D, Zapolska-D ownar A, Bukowska H, Galka H, Naruszewicz M. Ibuprofen protects low density lipoproteins against oxidative modification. Life Sci 1999; 65:2289-303

Zhang M, Storz G. Redox sens ing by prokaryotic transcriptionfactors.Bioc hemPharmacol2000;59:1-6 